\title{
Teachers' self-efficacy beliefs about pedagogical differentiation strategies
}

\author{
Sofia Ferreira Cândido \& José Castro Silva \\ CIE-ISPA, ISPA-Instituto Universitário, Lisbon, Portugal
}

\begin{abstract}
This paper reports the preliminary results of an investigation aimed at analyzing the interaction between teachers' self-efficacy beliefs about differentiated teaching strategies (instruction, behavior management, and collaboration) and the satisfaction of the basic needs for relatedness, autonomy, and competence. The participants were 861 Portuguese teachers from 1st to 9th grade (elementary to high school). For data collection purposes, three scales measuring Teacher Effectiveness for Inclusive Practices, the Teacher Professional Achievement Scale, and a questionnaire assessing Pedagogical Differentiation Strategies were used. Data were analyzed using exploratory and confirmatory factor analysis, structural equation modeling, correlations, and multiple regression analysis. Preliminary results show that experience predicts in a negative way teacher self-efficacy for using inclusive practices and in controlling behavioral effectiveness, as well as female teachers perceiving themselves as more competent in using inclusive teaching strategies. In addition, the results showed that female teachers perceive greater needs for relationship satisfaction and competence than male teachers. Finally, male teachers perceive themselves as having more difficulty in building inclusive environments.
\end{abstract}

Keywords: differentiated instruction; inclusive education; self-determination; collaboration; motivation 


\section{6-28 February, 2021 Amsterdam, Netherlands}

\section{Introduction}

Inclusive education is seen as global agenda and school inclusion enlist the right to education for all, regardless of physical characteristics, abilities, interests, and learning needs (CNE 2018; OECD 2012; Pereira et al., 2018; UNESCO, 1994; 2017). Therefore, it is necessary to respond to students' needs in order to provide quality education and boost participation and maximization of learning (UNESCO, 2015).

In this sense, and to address the difficulties that students may experience at any time in their educational pathway, it is necessary to foster diversity, not only in tasks and activities, but also in materials (Chtena, 2016), as well as to take into account the peculiar characteristics of students, such as cognitive styles, abilities, interests and personality (Morgado, 2004). Such information in conjunction with various types of assessment will help teachers respond to students' needs through multiple differentiated practices (Suprayogi, Valcke, \& Godwin, 2017), which will provide the teacher with the information needed to provide differentiated and quality responses for students (UNESCO, 2015). However, it is required that teachers are flexible (Pereira et al., 2018) and perceive themselves as being pedagogically competent, as the implementation of differentiated teaching strategies has been found to have a strong relationship with teacher efficacy (Holzberger, Philipp, \& Kunter, 2013), i.e., teachers with higher levels of efficacy are more ready to differentiate (Johnson, 2010) and have higher performance for the use of diverse approaches in the classroom (Klassen \& Tze, 2014), when compared to teachers with lower levels of efficacy (Johnson, 2010).

\section{Differentiated instruction}

Differentiated instruction is defined by Tomlinson and Allan (2002) as the way the teacher responds to students' needs, taking into account their interests, knowledge, experiences, needs and difficulties, and how the teacher monitors students' progress, specifically identifying what they need to learn and what they need to do to progress in their learning (Cadima 1997; Masters, 2010; Rose \& Gravel, 2009). Campbell (2008) sees differentiated instruction as a series of measures used to teach students with different competencies in a single classroom, taking into account their characteristics and previous experiences, in an educational environment suitable for all students, through multi-level and multi-skill teaching (Bantis, 2008), whereby the different backgrounds, readiness levels, language abilities, interests, and learning profiles of students must be recognized (Hall, 2002), so that a variety of knowledge and exposure techniques are offered to give them opportunities to demonstrate their learning (Tomlinson, 2001; Tomlinson \& Kalbfleisch, 1998).

Tomlinson and Allan (2002) state that teachers can respond to the needs of each student by differentiating in three areas: content, process, and products, according to the students' interests, learning profile, and receptivity, through a variety of pedagogical management strategies, resources, and teaching mechanisms (Israel, Ribuffo, \& Smith, 2014; Tomlinson, 2008; Tomlinson \& Allan, 2002).

Tomlinson (2008) also suggests that teachers must build confidence in the classroom through safe and flexible environments in which students can enjoy learning and how it is induced, both through the richness of the information and the various ways it is presented to them (i.e. 


\section{6-28 February, 2021 Amsterdam, Netherlands}

auditory, visual, and/or kinesthetic), which will provide a heterogeneity of stimuli and a mix of activities (Tomlinson, 2001; Tomlinson \& Allan, 2002). Teachers can also use different materials (e.g. videos, games, tokens) taking into account the students' interests (Tomlinson \& Allan, 2002), as well as their abilities and ways of working, in which the student can work individually or in heterogeneous or homogeneous groups, depending on the task presented to them (Pentecorvo, Ajellho, \& Zucchermaglio, 2005), which is in line with Gregory and Chapman (2002), since they point out that the flexible way of organizing group work promotes student participation and learning, since it encourages cooperative work and healthy competition (Tomlinson \& Allan, 2002).

To reach this goal, the teacher must engage and motivate students with achievable and learning-stimulating levels of challenge (Pereira et al, 2018), must plan activities focused with learning intentionality, promoting the teaching-learning process (Resendes \& Soares, 2002) through differentiation of educational practices, by which teachers aim to respond to diversity, so they are called the teacher's art tools, which can be used correctly or incorrectly, so it is up to the teacher to design and properly use each tool that is necessary to promote student success (Tomlinson \& Allan, 2002).

Bzuneck (2017) claims that in order to design and implement differentiation strategies, it is necessary for the teacher to have time, be flexible, be creative, use diversified materials, that is, a differentiated task constructor that facilitates learning. However, the literature also proposes that it is necessary to look at teacher self-efficacy, since teachers with a higher and more positive sense of efficacy (Ryan \& Deci, 2000) tend to design and implement more differentiated teaching strategies (Holzberger, Philipp, \& Kunter, 2013).

\section{Self-efficacy}

Bandura (1982, 1994, 1997) defines self-efficacy as a set of beliefs about own abilities to perform actions or tasks. These beliefs can be developed and strengthened by four sources: by direct experience lived by the subject (Bandura, 1994, 1997); by vicarious experience, in which the subject elaborates on his or her beliefs by learning from the successes and failures of others (Bandura, 1994; Wang \& Ertmer, 2003); by social persuasion, in which the subject is persuaded by feedback from others (Bandura, 1994, 1997); and by emotional states, from which the subject will react at the physiological level, since these tend to interfere with the subject's performance (Bandura, 1986; 1994; 1997; Bandura \& Locke, 2003). However, there are authors who state that one should also take into account the influences coming from the contexts where the subjects are inserted (Deci \& Ryan, 1985a), as well as personal and social factors, which can boost or undermine motivation. This thought was strengthened by Deci and Ryan (1985a) when they developed the self-determination theory (SDT), which is a motivational theory of personality and well-being, and was born from the analysis of social processes, in which the authors sought to analyze the individual differences of subjects and the social contexts and the influence they may have on motivation, in the sense of facilitating or hindering motivation (Ryan \& Deci, 2000).

\section{Motivation}

According to Eccles \& Wigfield (2002) motivation is an inner force that drives, guides and maintains the behavior of subjects. Therefore, individuals construct their motivation through their beliefs about what is important to them and their goals (Ames, 1992). However, because 


\section{6-28 February, 2021 Amsterdam, Netherlands}

it is an inner state, it is influenced by physical mechanisms, psychological and sociocultural variables, which together explain what and why the subject performed a certain behavior (Deci \& Ryan, 2008a; Fulmer and Frijters, 2009; Ryan \& Deci, 2000). Furthermore, motivation can be analyzed in two areas, namely intrinsic motivation and extrinsic motivation. Intrinsic motivation concerns the behavior performed out of interest and the characteristics of the task (Deci \& Ryan, 2000a; Deci, Vallerand, Pelletier, \& Ryan 1991; Niemiec \& Ryan, 2009), which provokes in the subject feelings of curiosity about the challenge and the pleasure he or she has in performing the activity (Deci \& Ryan, 1985a). Extrinsic motivation refers to behavior oriented toward obtaining a reward that is external to the task, that is, there is an external cause that can be material or psychological, which interferes with and guides the subject's behavior (Ryan \& Deci, 2000). In their selfdetermination theory, Deci and Ryan (1985a) also refer that subjects have basic needs for competence and self-determination (Deci \& Ryan, 1985a) and that they seek challenging activities, which they intrinsically find motivating, taking into account the basic need for competence that they have internalized, so that intrinsic motivation, according to the authors, only remains if subjects feel competent and self-determined (Deci \& Ryan, 2002). Thus, Deci and Ryan (1985a) evoke the importance of satisfying the three basic psychological needs, namely the need for competence (which refers to the ability of effectiveness and achievement that the subject has to develop a behavior); autonomy (which aims at the subject's ability to regulate his or her own actions, i.e. the perception that the subject has about the origin of the action and about his or her choices, which are supported by the subject's own genuine values and interests, free of coercion or external pressures (Deci \& Ryan, 2008; Ryan \& Deci, 2000); and closeness (which refers to the subject's ability to develop interpersonal relationships) (Reis, Sheldon, Gable, Roscoe, \& Ryan, 2000).

\section{Teachers' self-efficacy}

With regard to teachers, studies by Deci, Spiegel, Ryan, Koestner, and Kauffman (1982) revealed that teachers with greater autonomy were more intrinsically motivated and less likely to control their own students, so their students showed greater interest and pleasure in learning (Wild, Enzle, Nix, \& Deci,1997) than those of control-oriented (Deci, Schwartz, Sheinman, \& Ryan, 1981) and extrinsically motivated (Wild, Enzle, Nix, \& Deci, 1997) teachers. Thus, in the school context, perceived autonomy is related to several variables in the environment (e.g., the teacher's attitude, the subjects, the students) and with the various actors, focusing on the role of the teacher (Deci \& Ryan, 1985b; Ryan \& Deci, 2000), who should develop as much as possible his or her mastery experiences since it is one of the most important sources of teacher self-efficacy (Guskey \& Passaro, 1994; Tschannen-Moran, Hoy, \& Hoy, 1998) (defined as the teacher's ability to organize and accomplish tasks or actions (Bandura, 1997), as well as motivation, so that teachers can develop healthy learning environments (Bandura, 1997). Tschannen-Moran and Hoy (2001) view teacher self-efficacy as a teacher's judgment about his or her competence to improve not only student engagement but also academic achievement, regardless of the types of motivations. This is in line with the results of Usher and Pajares' (2008) study, as they found that teachers with high levels of selfefficacy used more teaching activities than teachers with low self-efficacy beliefs. Usher and Pajares (2008) also highlight other variables that can influence the formation and development of teacher self-efficacy such as age, gender, ethnicity, education, pedagogical skills (Usher \& Pajares, 2008) planning, organizational environment (Bzuneck, 2017; Fernandez, Ramos, Silva, Nina, \& Pontes, 2016; Holzberger, Philipp, \& Kunter, 2013; 


\section{3rd International Conference on}

\section{TEACHING, LEARNING and EDUCATION}

\section{6-28 February, 2021 Amsterdam, Netherlands}

Kleinsasser, 2014; Tschannen-Moran \& Hoy, 2007), and peer collaboration (Emmer \& Hickman, 1991). On the other hand, other studies suggest that teachers with high self-efficacy beliefs evaluate themselves as more effective at the pedagogical level, since they are able to perform more effective classroom management and promote the participation of all students (Brouwers \& Tomic, 2000; Caprara, Barbaranelli, Steca, \& Malone, 2006). In the same direction, Klassen and Chiu (2010) also found that teachers with higher self-efficacy achieve better classroom management, promote more experiences and carry out more educational activities in the classroom, without the problems of disruptive behaviors, so the teacher holds the ability to accommodate and respond to challenging students (Aloe, Amo, \& Shanahan, 2014), whereas teachers with low self-efficacy struggle to achieve a positive environment (Aloe, Amo, \& Shanahan, 2014; Marzano \& Marzano, 2003), as disruptive environments negatively affect the learning of all students (Pace, Boykins, \& Davis, 2014).

In summary, the literature shows that the purpose of differentiated instruction is to provide a quality, appropriate, and effective response to the educational needs of each student, as well as to promote equal opportunities in order to maximize the learning of all students, regardless of their physical-psycho-socio-cultural characteristics. Therefore, teachers with higher selfefficacy are more likely to act in various areas, such as adapting curricula, using different teaching methods, diversifying activities, using multiple resources, materials, and products, to adequately meet the needs and promote the learning of all students.

Taking into account the theoretical body presented above, the present study aimed to analyze the interplay between teachers' self-efficacy beliefs about differentiated teaching strategies (instruction, behavior management, and collaboration) and the satisfaction of the basic needs for relatedness, autonomy, and competence, as well as difficulties in implementing inclusive strategies and demographic characteristics.

\section{Method}

\section{Participants}

The research sample was non-randomized by convenience (Marôco, 2007; Marôco, 2010a), consisting of 861 elementary school teachers, aged between 23 and 68 years $(M=49.66$; $\mathrm{SD}=7.489$ ). Of these 161 were male and 700 were female. Data were collected from May to December 2020, in several urban and rural schools, located in Mainland Portugal, Autonomous Region of Madeira (RAM) and Autonomous Region of Azores (RAA).

\section{Teachers' sociodemographic characteristics}

\section{Gender}

The gender presents a heterogeneous distribution, since most of the teachers are female, i.e. $81.3 \%(\mathrm{n}=700)$ and the male gender is $18.7 \%(\mathrm{n}=161)$.

Age

The study sample, in terms of age, is distributed between 23 and 68 years, with $8.4 \%(n=73)$ being between 23 and 39 years, $81 \%(n=697)$ of the study sample presented between 40 and 59 years and $10.6 \%(n=91)$ is between 60 and 68 years.

Level of education that you teach in the current school year 


\section{3rd International Conference on}

\section{TEACHING, LEARNING and EDUCATION}

\section{6-28 February, 2021 Amsterdam, Netherlands}

With regard to the level of education, it was found that $33.3 \%$ of the respondents taught in the 1st cycle, $27.4 \%(n=287)$ in the 2ndcycle $(n=236)$ and $39.3 \%(n=338)$ in the $3^{\text {rd }}$ cycle of primary education.

\section{Recruitment Group}

The Recruitment Group refers to the joining together of several subjects into one group, i.e. Humanities (e.g. English, Portuguese, French, Latin, History) which represents $24.4 \%$ of the sample, 26.4\% in the Science group (Mathematics, Physics and Chemistry, Biology), 13.8\% in Expressions (Visual Education, Music Education, Physical Education) and 35.8\% for the Basic and Special E_ group (Basic Education and Special Education).

\section{Length of teaching service}

The teachers' length of service was grouped and adapted taking into account the model on professional life cycles by Gonçalves (2009), which has 5 classes of groupings.

Thus, in the study sample, $15.30 \%$ represent the first three stages (from 0 to 4 , from 5 to 7 years and from 8 to 15 years of experience) and $84.70 \%$ of the teachers are between the fourth (from 16 to 25 years of experience) and fifth (from 26 to 44 years of experience) stages.

\section{Procedure}

In order to carry out this study, permission was requested from the Directorate-General of Education (DGE) to apply questionnaires in schools. After the authorization has been granted, the group and school principals were contacted to request permission to administer the questionnaires to teachers; however, due to the pandemic, it was decided to send the questionnaire online, i.e., an e-mail presenting the study was sent, containing a direct link to the questionnaire. In case of agreement to participate in the study, the director forwarded the email to the teachers of the cluster or schools (schools that do not belong to any cluster). Several ethical and deontological principles were safeguarded in this study, such as informed consent, respect for data confidentiality, anonymity of participants, etc. (Baptista, 2014).

After data were collected, they were coded of and analyzed using IBM SPSS software (Statistics 26) (SPSS, 2017a) and IBM SPSS AMOS Statistics 26 software (SPSS, 2017b). To assess the validity of the measures, exploratory factor analysis (EFA) and confirmatory factor analyses were performed. To assess the reliability of the instruments, Cronbach's alpha was used and subsequently according to the nature of the data and the objectives of the work, as well as in order to explore the role of sociodemographic variables, namely teaching experience, recruitment group, age and gender, through correlation analysis, structural equation modeling and multiple regression analysis. 


\section{6-28 February, 2021 Amsterdam, Netherlands}

\section{Instruments}

The instruments used in this research were the Sense of Efficacy Scale to Implement Inclusive Practices (ESEIPI)((Dias, 2017), with 18 items distributed by 3 factors (efficacy in inclusive strategies $(\alpha 0.819)$; efficacy in controlling behaviors $(\alpha 0.853)$ and efficacy in collaboration ( $\alpha$ 0.910), assessed by a 6-point Likert-type scale: 1. (Strongly Disagree), 2. (Disagree), 3. (Partially Disagree), 4. (Partially Agree), 5. (Agree) and 6. (Totally Agree), which enables the subject to assess the degree of agreement or disagreement regarding the issues of self-efficacy in the implementation of inclusive practices (Dias, 2017); the Teacher Professional Attainment Scale (ERPD) (Granjo \& Peixoto, 2012) consisting of 16 items (assessed by a 6-point Liket-type scale, where 1 represents "Totally Disagree"; 2 "Disagree"; 3 "Somewhat Disagree"; 4 "Somewhat Agree"; 5 "Agree" and 6 "Totally Agree"), distributed over 3 dimensions: autonomy, competence, and relationship. The scale is designed to assess teachers' satisfaction with respect to the three basic needs, i.e. autonomy, competence and relationship (Granjo \& Peixoto, 2012); the Teachers' Differentiated Instructional Strategies Scale (TDISS) (Gaitas \& Martins, 2017) is composed of 39 items, divided into 5 dimensions (Planning and preparation; Classroom environment; Assessment practices; Classroom activities and materials; and Management, assessed using a 6-point Likert-type scale $(1=$ very easy, $2=$ easy, $3=$ somewhat difficult, $4=$ difficult, $5=$ very difficult, and $6=$ extremely difficult) and seeks to measure the difficulty perceived by teachers in implementing differentiated strategies in the classroom; a sociodemographic questionnaire, constructed by the authors, to collect personal and professional data (e.g., age, gender, academic qualifications, years of service, recruitment group, among others).

\section{Results}

Preliminary results

For the Sense of Efficacy to Implement Inclusive Practices Scale (ESEIPI) (Dias, 2017), an EFA was performed followed by a CFA.

The results of the EFA revealed a $\mathrm{KMO}=0.931$ Bartlett test $\mathrm{p}<0.0001$, a value that Pestana and Gageiro (2008) classified as very good. The extraction of the factors was previously determined according to Dias (2017) through the principal components method (PCM), followed by a Varimax rotation, for the final extraction of three factors, keeping the 18 items of the original scale.

With regard to the analysis of the internal consistency of the total scale, it was performed using Cronbach's alpha, which revealed a very good internal consistency ( $\alpha 0.92)$ (Pestana \& Gajeiro, 2008). In terms of the three factors, the items had factor weights higher than 0.50 , which were distributed by the respective factors. In terms of internal consistency, the factor effectiveness in collaboration $(\alpha 0.90)$ had a very good internal reliability, while the factors effectiveness in inclusive strategies $(\alpha 0.82)$ and effectiveness in behavioral control $(\alpha 0.85)$ had a good internal reliability, according to Pestana and Gageiro (2008). At the variance level, the three factors explained $61.33 \%$ of the total variance, with $23.76 \%$ for effectiveness 


\section{6-28 February, 2021 Amsterdam, Netherlands}

in behavior control, $19.92 \%$ for effectiveness in collaboration, and $17.65 \%$ effectiveness in inclusive strategies.

Based on the results of the EFA, we proceeded to the CFA of the model, with analysis of the correlation of measurement errors for the 18 items, distributed by the three latent factors, so the values (the $\mathrm{X}^{2} / \mathrm{gl}, 544.340 ; \mathrm{x} 2 \mathrm{df}=4.994 ; \mathrm{SRMR}=0.1471$; GFI=0.941; CFI=0.947; TIL= 0.925 ; RMSEA $=0.068$ (new model 1 ) of the model showed a good quality of adjustment (Marôco, 2010b).

For the Teacher Professional Attainment Scale (ERPD) (Granjo \& Peixoto, 2012), an EFA was performed followed by an CFA.

The results of the EFA revealed a KMO test $=0.91$; Bartlett $p<0.0001$, which is a value considered as very good, according to Pestana and Gageiro (2008). We proceeded to the extraction of 3 factors (as indicated by the model of Granjo and Peixoto (2012)), through the Principal Components Method (MCP), followed by a Varimax rotation, for the final extraction of the factors. After Varimax rotation, the low communality $(<40)$ led to the removal of 4 items $(01 ; 10 ; 14(\mathrm{r}) ; 15)$ from the 16 items of the original scale, which led to a final scale composed of 12 items.

Next, we analyzed the internal consistency of the total scale using Cronbach's alpha of 0.88 , i.e., a good internal consistency (Pestana \& Gajeiro, 2008). With regard to the latent factors, the items were distributed by their factors, thus an internal consistency factor with good internal reliability was found for the relationship ( $\alpha$ 0.85) and autonomy $(\alpha 0.81)$ and reasonable for competence $(\alpha 0.73)$ (Pestana \& Gageiro, 2008). At the level of variance, the three factors, these explain $64.86 \%$ of the total variance, being $26.85 \%$ for relationship, $19.35 \%$ for autonomy and $18.67 \%$ for competence.

Taking into account the results of the EFA we proceeded to the CFA of the model, with the correlation of measurement errors for the 12 items that were distributed by the three factors, it was found that the results (the $\mathrm{X}^{2} / \mathrm{gl}, 203.674$; $\mathrm{x} 2 \mathrm{df}=5.819$; SRMR=0.0303; GFI=0.974; CFI=0.969; TIL=0.942; RMSEA=0.063, confirm a good fit of the model (Marôco, 2007, 2010b).

For the Teachers' Differentiated Instructional Strategies Scale (TDISS)(Gaitas \& Martins, 2017) an CFA was performed.

The results of the CFA, regarding difficulty, were performed with the extraction of the latent factors as previously indicated by the author. Of the 39 items of the original scale, 9 items were removed for not presenting weights greater than 40 and that in the analysis harmed the model. Therefore, the final scale had 30 items, distributed by five latent factors, which, after analyzing the results $\left(\mathrm{X}^{2} / \mathrm{gl}=1523.898 ; \mathrm{x} 2 \mathrm{df}=4.075 ; \mathrm{SRMR}=0.0497 ; \mathrm{GFI}=0.880 ; \mathrm{CFI}=0.916\right.$; $\mathrm{TIL}=0.902$; RMSEA=0.060), revealed a good adjustment quality (Marôco, 2007, 2010b).

The internal consistency of the total scale was obtained through Cronbach's alpha, which showed a value of 0.96 , which proved to have a very good internal consistency (Pestana \& Gaveiro, 2008). The level of internal consistency for the five factors reported that the Environment factor ( $\alpha$ 0.83), Activities and materials ( $\alpha$ 0.87), Planning and Preparation ( $\alpha$ $0.82)$ had a good internal reliability, and the Management $(\alpha 0.76)$ and Assessment $(\alpha 0.80)$ factors had a reasonable internal reliability, according to Pestana and Gageiro (2008). 


\section{3rd International Conference on}

\section{TEACHING, LEARNING and EDUCATION}

\section{6-28 February, 2021 Amsterdam, Netherlands}

The structural equation analysis

The relationships between variables were estimated using structural equation modeling, and the model was developed based on the literature, being of an exploratory nature (Marôco, $2010 \mathrm{~b}$ ). In this sense, we tried to introduce the teaching experience into the model related to basic needs (relatedness, autonomy, and competence) and the self-efficacy model (efficacy in controlling behaviors, efficacy in collaboration, and efficacy in inclusive strategies).

After analyzing the basic needs model $\left(\mathrm{X}^{2} / \mathrm{gl}=256.156 ; \mathrm{x} 2 \mathrm{df}=4.494 ; \mathrm{SRMR}=0.0380\right.$; GFI=0.959; CFI=0.951; TIL=0.933; RMSEA=0.064), it showed a good quality of adjustment (Marôco, 2007, 2010b). After analyzing the model concerning self-efficacy (the $\mathrm{X}^{2} / \mathrm{gl}=491.065 ; \mathrm{x} 2 \mathrm{df}=3.665$; $\mathrm{SRMR}=0.0413 ; \mathrm{CFI}=0.956$; $\mathrm{TIL}=0.944$; RMSEA=0.056) this showed a good quality of fit (Marôco, 2007; 2010b).

We then proceeded to correlation analysis. With regard to the analysis of correlations, we tried to find out if there were correlations between the efficacy strategies and the satisfaction of basic needs. The analysis was performed using Spearman's rho coefficient, since the assumption of normality was not confirmed.

Table 1: Spearman's correlation coefficients between ESEIPI factors and ERPD factors

\begin{tabular}{|c|c|c|c|}
\hline \multirow[b]{2}{*}{ ESEIPI } & \multicolumn{3}{|c|}{ ERPD } \\
\hline & Relationship & Autonomy & Competence \\
\hline Inclusive Strategies Effectiveness &, $282^{* *}$ &, $246^{* * *}$ &, $485^{* *}$ \\
\hline Behavior Control Effectiveness &, $318^{* *}$ &, $222^{* *}$ &, $449^{* *}$ \\
\hline Collaborative Effectiveness &, $389^{* *}$ & $268^{* *}$ &, $509^{* *}$ \\
\hline
\end{tabular}

The results revealed the existence of statistically significant correlations between all ESEIPI and ERPD factors. With regard to the direction of relationships, it was found that the ERPD factors showed weak positive correlations between the relationship and autonomy and all the ESEIPI factors. With regard to competence, a moderate positive correlation was found with the three ESEIPI factors, i.e., with the effectiveness in inclusive strategies, in controlling behaviors and in collaboration.

Next, we sought to verify whether there were correlations between the effectiveness strategies, the satisfaction of the three basic needs and the difficulty in implementing differentiated strategies in the classroom.

Table 2: Spearman's correlation coefficients between ESEIPI factors, ERPD factors and TDISS factors

\begin{tabular}{|c|c|c|c|c|c|c|}
\hline & & \multicolumn{5}{|c|}{ TDISS } \\
\hline & & Environment & Management & Assessment & $\begin{array}{l}\text { Activities } \\
\text { Materials }\end{array}$ & $\begin{array}{c}\text { Planning } \\
\text { Preparation }\end{array}$ \\
\hline \multirow[t]{5}{*}{ ESEIPI } & Inclusive Strategies &,$- 328^{* *}$ &,$- 278^{* *}$ &,$- 285^{* *}$ &,$- 313^{* *}$ &,$- 301^{* *}$ \\
\hline & Effectiveness & & & & & \\
\hline & Behavior Control &,$- 276^{* *}$ &,$- 203^{* *}$ &,$- 200^{* *}$ &,$- 217^{* *}$ &,$- 233^{* *}$ \\
\hline & Effectiveness & & & & & \\
\hline & Collaborative Effectiveness &,$- 298^{* *}$ &,$- 205^{* *}$ &,$- 212^{* *}$ &,$- 240^{* *}$ &,$- 242^{* *}$ \\
\hline ERPD & Relationship &,$- 169^{* *}$ &,$- 120^{* *}$ &,$- 110^{* *}$ &,$- 105^{* *}$ &,$- 144^{* *}$ \\
\hline
\end{tabular}




\section{6-28 February, 2021 Amsterdam, Netherlands}

\begin{tabular}{llllll} 
Autonomy &,$- 231^{* *}$ &,$- 185^{* *}$ &,$- 192^{* *}$ &,$- 188^{* *}$ &,$- 200^{* *}$ \\
Competence &,$- 259^{* *}$ &,$- 192^{* *}$ &,$- 198^{* *}$ &,$- 202^{* *}$ &,$- 199^{* *}$ \\
\hline
\end{tabular}

**. Correlation is significant at the 0.01 level (2-tailed).

The results revealed the existence of statistically significant correlations between all favors of the three scales. With regard to the direction of relationships, it was found that the existence of negative correlations, weak between the three factors of the ESEIPI and the five factors of the TDISS, except the factor effectiveness in inclusive strategies, whose relationship between the difficulty of controlling the environment and planning and preparation, there was a moderate correlation. In relation to the ERPD, and with regard to the direction of relationships, there were negative correlations, very weak with the ESEIPI factors, except for autonomy and competence as there was a weak negative correlation with the difficulty in controlling the environment and a weak relationship between autonomy and difficulty in Planning and Preparation.

Following the analysis, we tried to find out if there were correlations between the ESEIPI, ERPD and TDISS factors and the sociodemographic variables: gender, age, recruitment group, level of education and length of service.

Therefore, the ESEIPI was analyzed and the following data were obtained.

Table 3: Spearman's correlation coefficients between ESEIPI factors and the sociodemographic variables

\begin{tabular}{|c|c|c|c|c|c|}
\hline ESEIPI & Gender & Age & $\begin{array}{l}\text { Recruiting } \\
\text { group }\end{array}$ & $\begin{array}{l}\text { Level of education } \\
\text { that teaches }\end{array}$ & $\begin{array}{l}\text { Time in } \\
\text { service }\end{array}$ \\
\hline $\begin{array}{l}\text { Inclusive Strategies } \\
\text { Effectiveness }\end{array}$ & 0,056 & $-0,022$ &, $197 * *$ &,$- 194 * *$ & $-0,018$ \\
\hline $\begin{array}{l}\text { Behavior Control } \\
\text { Effectiveness }\end{array}$ & 0,004 & $-0,016$ &, $165 * *$ &,$- 164 * *$ & $-0,004$ \\
\hline Collaborative Effectiveness &, $139 * *$ & $-0,011$ &, $269 * *$ &,$- 266 * *$ & 0,001 \\
\hline
\end{tabular}

**. Correlation is significant at the 0.01 level (2-tailed).

*. Correlation is significant at the 0.05 level (2-tailed).

As shown in table 3, there are significant correlations between some ESEIPI dimensions and the variables: gender, recruitment group and level of education. No correlations were found between the ESEIPI factors and age and length of service. With regard to the direction of relationships, very weak positive correlations can be found between gender and collaboration effectiveness. Regarding the recruitment group variable, there were very weak positive correlations between efficacy in inclusive strategies and efficacy in behavior control, and weak positive correlations in efficacy in collaboration. In the level of education that the teacher teaches, there were very weak negative correlations with the factors efficacy inclusive strategies and efficacy in controlling behavior, and weak negative correlations with the factor efficacy in collaboration.

In the analysis of the correlations between the RDSR and the sociodemographic variables: gender, age, recruitment group, teaching level, and length of service, the following results were found. 


\section{3rd International Conference on}

\section{TEACHING, LEARNING and EDUCATION}

\section{6-28 February, 2021 Amsterdam, Netherlands}

Table 4: Spearman's correlation coefficients between the ERPD factors and the sociodemographic variables

\begin{tabular}{|c|c|c|c|c|c|}
\hline ERPD & Gender & Age & $\begin{array}{l}\text { Recruiting } \\
\text { group }\end{array}$ & $\begin{array}{l}\text { Level of education } \\
\text { that teaches }\end{array}$ & Time in service \\
\hline Relationship &, $079^{*}$ &, $067^{*}$ &, $082^{*}$ & $-0,046$ &, $081^{*}$ \\
\hline Autonomy & 0,049 & $-0,065$ & 0,054 & $-0,021$ & $-0,009$ \\
\hline Competence &, $131^{* *}$ & $-0,054$ &, $127^{* *}$ &,$- 093^{* *}$ & 0,003 \\
\hline
\end{tabular}

**. Correlation is significant at the 0.01 level (2-tailed).

*. Correlation is significant at the 0.05 level (2-tailed).

As a result (table 4), significant correlations were found between some dimensions of the DBES and the variables: gender, age, recruitment group, level of education and length of service.

Thus, for gender, it was found that the direction of the relationships were very weak positive correlations with relatedness and competence. As for age, there were very weak negative correlations with relatedness. In the recruitment group, very weak positive correlations were observed with relatedness and with competence. The level of education that the teacher teaches in the current school year showed very weak negative correlations with competence. And lastly, the length of service variable showed very weak positive correlations with the relatedness dimension.

Finally, the TDISS factors and the sociodemographic variables: gender, age, recruitment group, teaching level, and length of service were analyzed for correlations, and the following results were found.

Table 5: Spearman's correlation coefficients between TDISS factors and sociodemographic variables

\begin{tabular}{|c|c|c|c|c|c|}
\hline TDISS & Gender & Age & $\begin{array}{l}\text { Recruiting } \\
\text { group }\end{array}$ & $\begin{array}{c}\text { Level of } \\
\text { education that } \\
\text { teaches }\end{array}$ & $\begin{array}{l}\text { Time in } \\
\text { service }\end{array}$ \\
\hline Environment &,$- 086^{*}$ & $-0,006$ &,$- 119^{* *}$ &, $139^{* *}$ & 0,000 \\
\hline Management & $-0,060$ & $-0,008$ &,$- 097^{* * *}$ &, $071^{*}$ & 0,003 \\
\hline Assessment & $-0,045$ & 0,014 &,$- 087^{*}$ &, $074^{*}$ & 0,017 \\
\hline Activities Materials & $-0,045$ & $-0,012$ &,$- 102^{* *}$ &, $103^{* *}$ & 0,002 \\
\hline Planning Preparation & $-0,039$ & $-0,030$ &,$- 123^{* *}$ &, $102^{* *}$ & $-0,004$ \\
\hline
\end{tabular}

As a result, it is visible in table 5, significant correlations between some TDISS dimensions and the variables: gender, recruitment group and level of education, and no correlation was found between the TDISS factors, age and length of service. With regard to the direction of relationships, there was a very weak negative correlation between the classroom environment factor and gender. For the recruitment group, there was found to be a weak negative correlation with all of the TDISS factors. For the level of education, the opposite was found, i.e., a weak positive correlation with all TDISS factors. 


\section{3rd International Conference on}

\section{TEACHING, LEARNING and EDUCATION}

\section{viatle}

\section{6-28 February, 2021 Amsterdam, Netherlands}

Taking into account the above-mentioned results at the level of correlations, we also decided to check whether some variables are able to predict others, so we proceeded with a regression analysis (Marôco, 2010b).

\section{Multiple linear regression analysis}

Multiple linear regression makes it possible to model relationships between several variables and predict the value of a dependent (i.e., response) variable from a set of independent (predictor) variables (Marôco, 2010b), so we used multiple linear regression analysis to examine whether the independent variables: gender, age, recruitment group, level of education and length of service and teaching experience, are able to predict (the dependent variables or factors of the three scales) effectiveness (effectiveness in inclusive strategies, collaboration and behavior), the satisfaction of basic needs (relationship, competence and autonomy) and the difficulties (classroom environment) of implementing differentiated strategies.

After checking the assumptions (minimum $\mathrm{n}$ of 20 , by VI; independent residuals (DurdinWatson test), absence of multicollinearity (Tolerance $>0.1$; VIF less than 10), absence of outliers (the values should be between -3 and +3 ), normally distributed residuals (P-Plot) and homoscedasticity (Scartterplot) (Marôco, 2007), the presence of outliers and asymmetric residuals was verified.

Therefore, multiple linear regression was used to examine whether teaching experience, recruitment group, gender, and length of service in the school are able to predict effectiveness in inclusive strategies, satisfaction of the need for relatedness and competence, and predict classroom environment.

\section{Effectiveness in Inclusive Strategies}

Multiple liner regression was used to see if length of service, recruitment group, gender, teaching level, and length of service in the school are able to predict effectiveness in inclusive strategies.

\begin{tabular}{|c|c|c|c|c|c|c|c|c|c|c|}
\hline \multicolumn{11}{|c|}{ Model Summary $^{\mathrm{b}}$} \\
\hline Model & $\mathrm{R}$ & $\begin{array}{l}\mathrm{R} \\
\text { Square }\end{array}$ & $\begin{array}{l}\text { Adjusted } \\
\text { R Square }\end{array}$ & $\begin{array}{l}\text { Std. Error } \\
\text { of the } \\
\text { Estimate }\end{array}$ & $\begin{array}{l}\text { R Square } \\
\text { Change }\end{array}$ & F Change & df1 & df 2 & $\begin{array}{l}\text { Sig. F } \\
\text { Change }\end{array}$ & $\begin{array}{l}\text { Durbin- } \\
\text { Watson }\end{array}$ \\
\hline 1 &, $215^{\mathrm{a}}$ & ,046 & 0,041 & 0,62752 & 0,046 & 8,293 & 5 & 854 & .000 & 1,841 \\
\hline
\end{tabular}

ANOVA $^{\mathrm{a}}$

\begin{tabular}{cccccccc} 
Model & & Sum of Squares & df & Mean Square & F & Sig. \\
\hline 1 & Regression & 16,328 & 5 & 3,266 & 8,293 &, $000^{\mathrm{b}}$
\end{tabular}




\section{6-28 February, 2021 Amsterdam, Netherlands}

\begin{tabular}{|c|c|c|c|c|c|c|}
\hline & \multirow{2}{*}{$\begin{array}{l}\text { Residual } \\
\text { Total }\end{array}$} & \multicolumn{2}{|l|}{336,285} & 0,394 & & \\
\hline & & 352,613 & 859 & & & \\
\hline \multicolumn{7}{|c|}{$\begin{array}{l}\text { b. Predictors: (Constant), Level of education, Length of service at school, Gender, Length of service, } \\
\text { Recruitment group }\end{array}$} \\
\hline \multicolumn{7}{|c|}{ Coefficients $^{\mathrm{a}}$} \\
\hline \multirow[t]{3}{*}{ Model } & & \multicolumn{2}{|c|}{$\begin{array}{l}\text { Unstandardized } \\
\text { Coefficients }\end{array}$} & \multirow{2}{*}{$\begin{array}{l}\text { Standardized } \\
\text { Coefficients } \\
\end{array}$} & \multirow[b]{3}{*}{$\mathrm{t}$} & \multirow[b]{3}{*}{ Sig. } \\
\hline & & & Std. & & & \\
\hline & & B & Error & Beta & & \\
\hline \multirow[t]{6}{*}{1} & (Constant) & 4,850 & 0,192 & & 25,268 & 0,000 \\
\hline & Gender & 0,119 & 0,055 & 0,073 & 2,154 & 0,032 \\
\hline & Recruitment group & 0,065 & 0,025 & 0,123 & 2,629 & 0,009 \\
\hline & Length of service & $-0,050$ & 0,025 & $-0,075$ & $-1,981$ & 0,048 \\
\hline & Length of service at school & 0,019 & 0,013 & 0,055 & 1,452 & 0,147 \\
\hline & Level of education that teaches & $-0,061$ & 0,035 & $-0,082$ & $-1,745$ & 0,081 \\
\hline
\end{tabular}

a. Dependent Variable: Inclusive Strategies Effectiveness

Linear regression identified recruitment group $(\beta=0.123 ; \mathrm{T}=2.629 ; \mathrm{p}<0.001)$, gender $(\beta=0.073 ; \mathrm{T}=2.154 ; \mathrm{p}<0.001)$ and length of service $(\beta=-0.075 ; \mathrm{T}=-1.981 ; \mathrm{p}<0.001)$ as significant predictors of effectiveness in inclusive strategies, with the first two being positive predictors and length of service a negative predictor. The remaining variables are not significant to the model. The final adjusted model is statistically significant, but weak, and explains a proportion of the observed variety in the variable effectiveness in inclusive strategies of a significant $4.6 \%[F(5,854)=8.293 ; \mathrm{p}<0.001: \mathrm{R} 2=0.046]$.

Preliminary results showed that teaching experience predicts in a negative way teachers' selfefficacy in using inclusive practices, as well as female teachers (female $\mathrm{M}=4.98, \mathrm{SD}=0.62$; male $\mathrm{M}=4.84, \mathrm{SD}=0.73$ ) consider themselves more competent in using inclusive teaching strategies, as well as the use in using inclusive practices by elementary and special education teachers (Humanities $\mathrm{M}=4.8, \mathrm{SD}=0.66$; Science $\mathrm{M}=4.90, \mathrm{SD}=0.63$; Expressions $\mathrm{M}=4.91$, $\mathrm{SD}=0.64$; E. Basic and E. Special Education $\mathrm{M}=5.10, \mathrm{SD}=0.61$ )

\section{Effectiveness in managing behaviors}

Multiple liner regression was used to see if length of service in school, level of education, gender, length of service, recruitment group, are able to predict efficacy in managing behaviors.

\begin{tabular}{|c|c|c|c|c|c|c|c|c|c|c|}
\hline \multicolumn{11}{|c|}{ Model Summary } \\
\hline Model & $\mathrm{R}$ & $\begin{array}{l}\mathrm{R} \\
\text { Square }\end{array}$ & $\begin{array}{l}\text { Adjusted } \\
\text { R Square }\end{array}$ & $\begin{array}{l}\text { Std. Error } \\
\text { of the } \\
\text { Estimate }\end{array}$ & $\begin{array}{l}\text { R Square } \\
\text { Change }\end{array}$ & F Change & df1 & df2 & $\begin{array}{c}\text { Sig. F } \\
\text { Change }\end{array}$ & $\begin{array}{l}\text { Durbin- } \\
\text { Watson }\end{array}$ \\
\hline 1 &, $169^{\mathrm{a}}$ & ,029 & 0,023 & 0,70586 & 0,029 & 5,019 & 5 & 854 & .000 & 1,960 \\
\hline
\end{tabular}




\section{6-28 February, 2021 Amsterdam, Netherlands}

b. Dependent Variable: Behavior Effectiveness

\section{ANOVA $^{\mathrm{a}}$}

\begin{tabular}{|c|c|c|c|c|c|c|c|}
\hline \multicolumn{3}{|l|}{ Model } & Sum of Squares & df & Mean Square & $\mathrm{F}$ & Sig. \\
\hline & 1 & Regression & 12,599 & 5 & 2,520 & 5,019 &, $000^{\mathrm{b}}$ \\
\hline & & Residual & 428,758 & 854 & 0,502 & & \\
\hline & & Total & 441,356 & 859 & & & \\
\hline
\end{tabular}

a. Dependent Variable: Behavior Effectiveness

b. Predictors: (Constant), Length of service at school, Level of education, Gender, Length of service,

Recruitment group

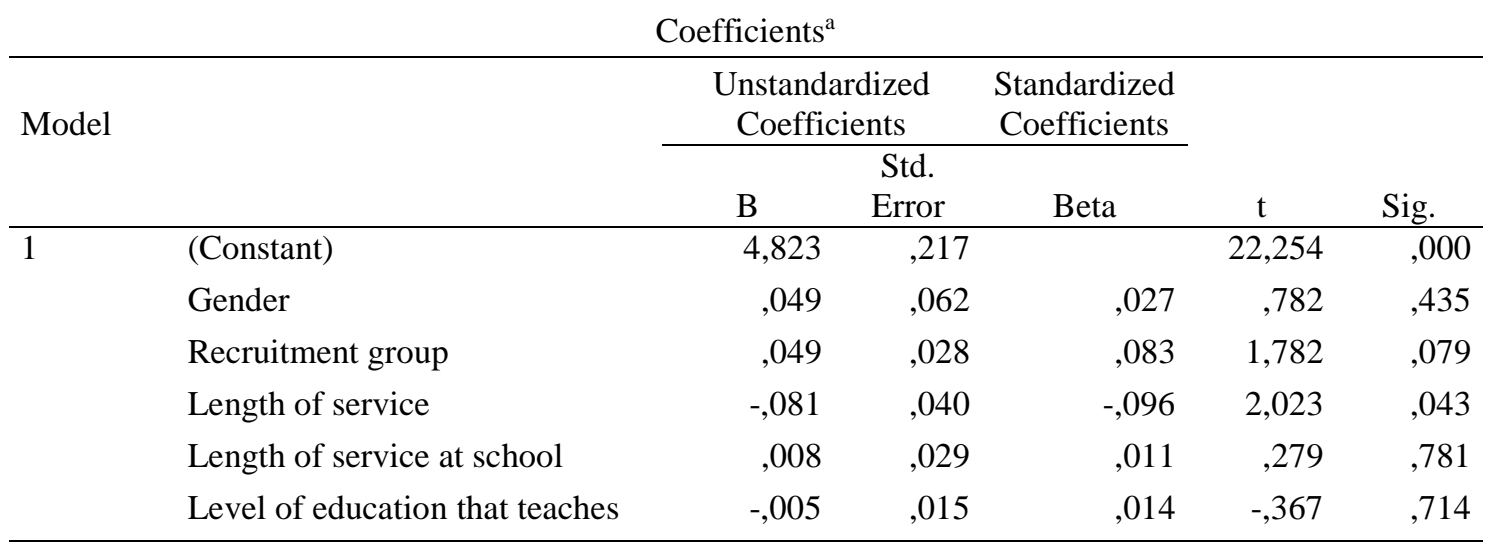

a. Dependent Variable: Behavior Effectiveness

Linear regression identified that the level that the teacher teaches $(\beta=-.096 ; \mathrm{T}=-2.023$; $\mathrm{p}<0.001)$ is a significant but negative predictor of behavior effectiveness. The remaining variables are not significant to the model. The final adjusted model is statistically significant, but weak, and explains a proportion of the observed variety in the behavior effectiveness variable of $2.9 \%[\mathrm{~F}(5.854)=5.019 ; \mathrm{p}<0.001: \mathrm{R} 2=0.029]$,

Preliminary results showed that the grade level at which teachers teach negatively predicts teachers' self-efficacy in controlling behaviors, i.e., 1st grade teachers (1st CEB $\mathrm{M}=5.03$, $\mathrm{SD}=0.65 ;$ 2nd $\mathrm{CEB} \mathrm{M}=4.91, \mathrm{SD}=0.67$; 3rd $\mathrm{CEB} \mathrm{M}=4.77, \mathrm{SD}=0.78$ ) perceive themselves with more self-efficacy in controlling behaviors

\section{Efficacy in collaboration}

Multiple liner regression was used to examine whether level of education, length of service in school, gender, length of service, recruitment group, are able to predict collaborative efficacy.

Model Summary ${ }^{\mathrm{b}}$

\begin{tabular}{|c|c|c|c|c|c|c|c|c|c|c|}
\hline Model & $\mathrm{R}$ & $\begin{array}{l}\mathrm{R} \\
\text { Square }\end{array}$ & $\begin{array}{l}\text { Adjusted } \\
\text { R Square }\end{array}$ & $\begin{array}{l}\text { Std. Error } \\
\text { of the } \\
\text { Estimate }\end{array}$ & $\begin{array}{l}\text { R Square } \\
\text { Change }\end{array}$ & F Change & df1 & df 2 & $\begin{array}{c}\text { Sig. F } \\
\text { Change }\end{array}$ & $\begin{array}{l}\text { Durbin- } \\
\text { Watson }\end{array}$ \\
\hline
\end{tabular}




\section{6-28 February, 2021 Amsterdam, Netherlands}

\begin{tabular}{rrrrrrrrrrr}
1 & $1317^{\mathrm{a}}$ &, 101 &, 095 &, 69650 &, 101 & 19,135 & 5 & 854 & .000 & 1,898 \\
\hline
\end{tabular}

a. Predictors: (Constant), Length of service at school, Level of education, Gender, Length of service, Recruitment group

b. Dependent Variable: Collaboration Effectiveness

\begin{tabular}{|c|c|c|c|c|c|c|c|}
\hline \multicolumn{8}{|c|}{ ANOVA $^{\mathrm{a}}$} \\
\hline Model & & & Sum of Squares & df & Mean Square & $\mathrm{F}$ & Sig. \\
\hline & 1 & Regression & 46,413 & 5 & 9,283 & 19,135 &, $000^{\mathrm{b}}$ \\
\hline & & Residual & 414,288 & 854 & ,485 & & \\
\hline & & Total & 460,701 & 859 & & & \\
\hline
\end{tabular}

a. Dependent Variable: Collaboration Effectiveness

b. Predictors: (Constant), Length of service at school, Level of education, Gender, Length of service, Recruitment group

\begin{tabular}{|c|c|c|c|c|c|c|}
\hline \multicolumn{7}{|c|}{ Coefficients $^{\mathrm{a}}$} \\
\hline \multirow[t]{3}{*}{ Model } & & \multicolumn{2}{|c|}{$\begin{array}{c}\text { Unstandardized } \\
\text { Coefficients }\end{array}$} & \multirow[t]{2}{*}{$\begin{array}{l}\text { Standardized } \\
\text { Coefficients }\end{array}$} & \multirow[b]{3}{*}{$\mathrm{t}$} & \multirow[b]{3}{*}{ Sig. } \\
\hline & & & Std. & & & \\
\hline & & $\mathrm{B}$ & Error & Beta & & \\
\hline \multirow[t]{6}{*}{1} & (Constant) & 4,438 & ,213 & & 20,830 &, 000 \\
\hline & Gender &, 274 &, 061 & , 146 & 4,454 &, 000 \\
\hline & Recruitment group & ,090 & ,028 & , 148 & 3,272 &, 001 \\
\hline & Length of service &, 007 & 028 & ,010 & ,264 & ,792 \\
\hline & Length of service at school &,- 020 &, 015 &,- 049 & $-1,334$ &, 103 \\
\hline & Level of education that teaches &,- 124 & 039 &,- 144 & $-3,174$ &, 002 \\
\hline
\end{tabular}

a. Dependent Variable: Collaboration Effectiveness

Recruitment $(\beta=0,148 ; \mathrm{T}=3.272 ; \mathrm{p}<0.001)$ and level of education $(\beta=-0.144 ; \mathrm{T}=--3.174$; $\mathrm{p}<0.001)$ emerged as significant predictors of collaboration effectiveness, with the first two being positive predictors and education level being a negative predictor. The remaining variables are not significant to the model. The final adjusted model is statistically significant, but weak, and explains a proportion of the observed variety in the collaboration effectiveness variable of $10 \%[\mathrm{~F}(5,854)=19.135 ; \mathrm{p}<0.001: \mathrm{R} 2=0,101]$.

Preliminary results showed that gender and recruitment group, are significant and positive predictors, collaboration efficacy, and teaching level, predicts in a negative way teachers' self-efficacy in collaboration, that is, female teachers (female $M=4.91, S D=0.68$; male $M=4.84, S D=0.85$ ) of elementary and special education (Humanities $M=4.78, S D=0.69$; Science $M=4.80, S D=0.77$; Expressions $\mathrm{M}=4.89, \mathrm{SD}=0.78$; E. Elementary and E. Special Education $M=5.03, S D=0.64)$ to perceive themselves with higher self-efficacy in collaboration.

\section{Relatedness}




\section{3rd International Conference on}

\section{TEACHING, LEARNING and EDUCATION}

\section{6-28 February, 2021 Amsterdam, Netherlands}

Multiple liner regression was used to examine whether teaching level, length of service in the school, gender, length of service, recruitment group, are able to predict the basic need for relatedness.

\begin{tabular}{rrrrrrrrrrrr} 
Model & $\mathrm{R}$ & $\begin{array}{l}\mathrm{R} \\
\text { Square }\end{array}$ & $\begin{array}{c}\text { Adjusted } \\
\text { R Square }\end{array}$ & $\begin{array}{c}\text { Model Summary } \\
\text { of the } \\
\text { Estimate }\end{array}$ & $\begin{array}{c}\text { R Square } \\
\text { Change }\end{array}$ & F Change & df1 & df2 & $\begin{array}{c}\text { Sig. F } \\
\text { Change }\end{array}$ & $\begin{array}{c}\text { Durbin- } \\
\text { Watson }\end{array}$ \\
\hline 1 &, $152^{\mathrm{a}}$ &, 023 &, 017 &, 74818 &, 023 & 4,018 & 5 & 854 & .001 & 2,052 \\
\hline
\end{tabular}

a. Predictors: (Constant), Length of service at school, Level of education, Gender, Length of service, Recruitment group

b. Dependent Variable: Relationship

ANOVA $^{\mathrm{a}}$

\begin{tabular}{llrrrrr} 
& & Sum of Squares & df & Mean Square & \multicolumn{1}{c}{ F } & \multicolumn{1}{c}{ Sig. } \\
\hline 1 & Regression & 11,245 & 5 & 2,249 & 4,018 &, $001^{\mathrm{b}}$ \\
& Residual & 478,045 & 854 &, 560 & & \\
& Total & 489,290 & 859 & & & \\
\hline
\end{tabular}

a. Dependent Variable: Relationship

b. Predictors: (Constant), Length of service at school, Level of education, Gender, Length of service,

Recruitment group

\begin{tabular}{|c|c|c|c|c|c|c|}
\hline \multicolumn{7}{|c|}{ Coefficients ${ }^{\mathrm{a}}$} \\
\hline \multirow[t]{3}{*}{ Model } & & \multicolumn{2}{|c|}{$\begin{array}{l}\text { Unstandardized } \\
\text { Coefficients }\end{array}$} & \multirow{3}{*}{$\begin{array}{c}\begin{array}{c}\text { Standardized } \\
\text { Coefficients }\end{array} \\
\text { Beta }\end{array}$} & \multirow[b]{3}{*}{$\mathrm{t}$} & \multirow[b]{3}{*}{ Sig. } \\
\hline & & & Std. & & & \\
\hline & & B & Error & & & \\
\hline \multirow[t]{6}{*}{1} & (Constant) & 4,087 & ,229 & & 17,857 &, 000 \\
\hline & Gender &, 169 & ,066 &, 087 & 2,558 &, 011 \\
\hline & Recruitment group & 064 & 030 &, 101 & 2,146 & 032 \\
\hline & Length of service &, 032 & ,030 &, 040 & 1,045 & ,296 \\
\hline & Length of service at school & 028 &, 016 &, 067 & 1,753 & 080 \\
\hline & Level of education that teaches & 039 & 042 & 044 & ,934 &, 350 \\
\hline
\end{tabular}

a. Dependent Variable: Relationship

Linear regression analysis identified gender $(\beta=0.087 ; \mathrm{T}=2.558 ; \mathrm{p}<0.001)$ and recruitment group $(\beta=0.101 ; \mathrm{T}=2.146 ; \mathrm{p}<0.001)$ as significant predictors in relatedness need. The remaining variables are not significant for the model. 


\section{3rd International Conference on}

\section{TEACHING, LEARNING and EDUCATION}

\section{6-28 February, 2021 Amsterdam, Netherlands}

The final adjusted model is statistically significant, but weak, and explains a proportion of the observed variety in the relationship need variable of $2.3 \%[\mathrm{~F}(5,854)=4.018 ; \mathrm{p}<0.001$ : $\mathrm{R} 2=$ $0,023]$.

Preliminary results showed that gender and recruitment group, are significant and positive predictors, on the need for relationship, i.e., female teachers (female $M=4.89, S D=0.73$; male $M=4.70, S D=0.85$ ) of elementary and special education (Humanities $M=4.74, S D=0.79$; Science $M=4.87, S D=0.72$; Expressions $M=4.88, S D=0.72$; E. Elementary and E. Special $M=4.90, S D=0.76$ ) to perceive themselves with a need for relatedness.

\section{Autonomy}

Multiple linear regression was used to verify if the level of education, length of service in the school, gender, length of service, recruitment group, are able to predict the basic need for autonomy. After analysis, it was found that the variables are not significant in predicting the need for autonomy.

\section{Competence}

Multiple linear regression was used to verify if the level of education, length of service in the school, gender, length of service, recruitment group, are able to predict the basic need for competence.

\begin{tabular}{rrrrrrrrrrr}
\multicolumn{10}{c}{ Model Summary } \\
Model & $\mathrm{R}$ & $\begin{array}{l}\mathrm{R} \\
\text { Square }\end{array}$ & $\begin{array}{c}\text { Adjusted } \\
\text { R Square }\end{array}$ & $\begin{array}{c}\text { Std. Error } \\
\text { of the } \\
\text { Estimate }\end{array}$ & $\begin{array}{c}\text { R Square } \\
\text { Change }\end{array}$ & F Change & df1 & df2 & $\begin{array}{c}\text { Sig. F } \\
\text { Change }\end{array}$ & $\begin{array}{l}\text { Durbin- } \\
\text { Watson }\end{array}$ \\
\hline 1 &, $183^{\mathrm{a}}$ &, 033 &, 028 &, 67465 &, 033 & 5,890 & 5 & 854 & .000 & 1,974 \\
\hline
\end{tabular}

a. Predictors: (Constant), Length of service at school, Level of education, Gender, Length of service, Recruitment group

b. Dependent Variable: Competence

\begin{tabular}{|c|c|c|c|c|c|c|c|}
\hline \multicolumn{8}{|c|}{ ANOVA $^{\mathrm{a}}$} \\
\hline Model & & & Sum of Squares & df & Mean Square & $\mathrm{F}$ & Sig. \\
\hline & 1 & Regression & 13,404 & 5 & 2,681 & 5,890 &, $000^{\mathrm{b}}$ \\
\hline & & Residual & 388,702 & 854 &, 560 & & \\
\hline & & Total & 402,106 & 859 & & & \\
\hline
\end{tabular}

a. Dependent Variable: Competence

b. Predictors: (Constant), Length of service at school, Level of education, Gender, Length of service, Recruitment group 


\section{3rd International Conference on}

TEACHING, LEARNING and EDUCATION

\section{Viatle}

\section{6-28 February, 2021 Amsterdam, Netherlands}

\begin{tabular}{|c|c|c|c|c|c|c|}
\hline \multicolumn{7}{|c|}{ Coefficients $^{\mathrm{a}}$} \\
\hline \multirow[t]{3}{*}{ Model } & & \multicolumn{2}{|c|}{$\begin{array}{c}\text { Unstandardized } \\
\text { Coefficients }\end{array}$} & \multirow{3}{*}{$\begin{array}{c}\text { Standardized } \\
\text { Coefficients } \\
\text { Beta }\end{array}$} & \multirow[b]{3}{*}{$\mathrm{t}$} & \multirow[b]{3}{*}{ Sig. } \\
\hline & & & Std. & & & \\
\hline & & B & Error & & & \\
\hline \multirow[t]{6}{*}{1} & (Constant) & 4,393 & ,206 & & 21,287 &, 000 \\
\hline & Gender & ,236 &, 059 & 135 & 3,967 &, 000 \\
\hline & Recruitment group & ,063 & ,027 &, 110 & 2,349 & ,019 \\
\hline & Length of service &,- 048 & ,027 &,- 067 & $-1,742$ & ,082 \\
\hline & Length of service at school & 017 & ,014 &, 047 & 1,227 & ,220 \\
\hline & Level of education that teaches & ,003 & ,038 & ,004 & ,080 & ,936 \\
\hline
\end{tabular}

a. Dependent Variable: Competence

Linear regression analysis identified gender $(\beta=0.236 ; \mathrm{T}=3.967 ; \mathrm{p}<0.001)$ and recruitment group $(\beta=0.063 ; \mathrm{T}=2.349 ; \mathrm{p}<0.001)$ as significant, positive predictors of the need for competence. The remaining variables are not significant for the model.

The final adjusted model is statistically significant, but weak, and explains a proportion of the observed variety in the need for competence variable of $3.3 \%[\mathrm{~F}(5.854)=5.890 ; \mathrm{p}<0.001$ : $\mathrm{R} 2=0,033]$.

Table 6: The Competence in Recruitment Group VS Gender

\begin{tabular}{cccccc}
\hline Gender & & Humanities & Sciences & Expressions & $\begin{array}{c}\text { Elementary and } \\
\text { Special Education }\end{array}$ \\
\hline \multirow{2}{*}{ Female } & $M$ & 4,78 & 4,85 & 4,87 & 4,98 \\
& $S D$ & 0,73 & 0,63 & 0,67 & 0,60 \\
Male & $M$ & 4,49 & 4,69 & 4,71 & 4,66 \\
\hline
\end{tabular}

Preliminary results showed that gender and recruitment group, are significant and positive predictors, on the need for relatedness, that is, teachers (female $M=4.88, S D=0.65$; male $M=4.65, S D=0.75$ ) from elementary school and special education (see table 6) perceiving themselves with a greater need for competence.

\section{Teachers' beliefs about differentiated instructional strategies}

Multiple linear regression was used to examine whether level of education, length of service in school, gender, length of service, recruitment group, are able to predict the difficulty to manage learning environment.

\section{Model Summary ${ }^{\mathrm{b}}$}

\begin{tabular}{|c|c|c|c|c|c|c|c|c|c|c|}
\hline Model & $\mathrm{R}$ & $\begin{array}{l}\mathrm{R} \\
\text { Square }\end{array}$ & $\begin{array}{l}\text { Adjusted } \\
\text { R Square }\end{array}$ & $\begin{array}{l}\text { Std. Error } \\
\text { of the } \\
\text { Estimate }\end{array}$ & $\begin{array}{c}\text { R Square } \\
\text { Change }\end{array}$ & F Change & df1 & df2 & $\begin{array}{c}\text { Sig. F } \\
\text { Change }\end{array}$ & $\begin{array}{l}\text { Durbin- } \\
\text { Watson }\end{array}$ \\
\hline
\end{tabular}

\begin{tabular}{lllllllllll}
\hline 1 &, $161^{\mathrm{a}}$ &, 026 &, 026 & 1,10327 &, 026 & 4,546 & 5 & 854 & .001 & 1,054 \\
\hline
\end{tabular}

a. Predictors: (Constant), Length of service at school, Level of education, Gender, Length of service,

Recruitment group 


\section{3rd International Conference on}

\section{TEACHING, LEARNING and EDUCATION}

\section{6-28 February, 2021 Amsterdam, Netherlands}

b. Dependent Variable: Learning environment management

\begin{tabular}{|c|c|c|c|c|c|c|c|}
\hline \multicolumn{8}{|c|}{ ANOVA $^{\mathrm{a}}$} \\
\hline Model & & & Sum of Squares & df & Mean Square & $\mathrm{F}$ & Sig. \\
\hline & & Regression & 27,668 & 5 & 5,534 & 4,546 &, $000^{\mathrm{b}}$ \\
\hline & & Residual & 1039,492 & 854 &, 560 & & \\
\hline & & Total & 1067,159 & 859 & & & \\
\hline
\end{tabular}

a. Dependent Variable: Learning environment management

b. Predictors: (Constant), Length of service at school, Level of education, Gender, Length of service,

Recruitment group

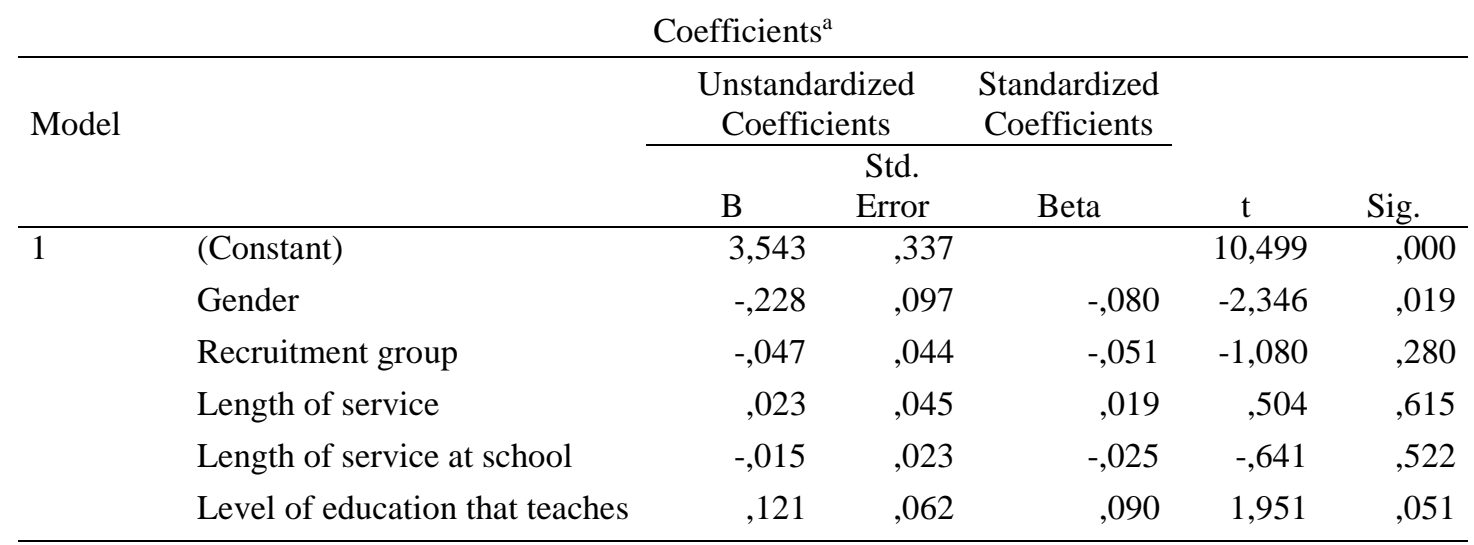

a. Dependent Variable: Learning environment management

Linear regression analysis identified gender $(\beta=-.080 ; \mathrm{T}=-2.346 ; \mathrm{P}=0.019)$ as significant, positive predictors of the need for competence. The remaining variables are not significant for the model. The final adjusted model is statistically significant, but weak, and explains a proportion of the observed variety in the variable difficulty in learning environment management of $2.6 \%$ [F $(5.854)=4.546 ; \mathrm{p}<0.001: \mathrm{R} 2=0.026]$.

Finally, male teachers (female $M=3.26, S D=1.11$; male $M=3.52, S D=1.11$ ) are pushing themselves harder to instruct in inclusive settings. In order to ascertain whether self-efficacy was a predictor of difficulties in implementing differentiated strategies (competence, efficacy inclusive strategies, autonomy, efficacy behavior control, relatedness, collaboration efficacy) a regression analysis was conducted.

After checking the assumptions (minimum $\mathrm{n}$ of 20, by VI; independent residuals (DurdinWatson test), absence of multicollinearity (Tolerance $>0.1$; VIF less than 10), absence of outliers (values should be between -3 and +3 ), normally distributed residuals (P-Plot), and homoscedasticity (Scartterplot) (Marôco, 2007). After analyzing the assumptions, it was found that all assumptions were confirmed. Multiple linear regression was used to verify if level of education, length of service in school, gender, length of service, recruitment group, are able to predict the learning environment management 


\section{6-28 February, 2021 Amsterdam, Netherlands}

\begin{tabular}{|c|c|c|c|c|c|c|c|c|c|c|}
\hline \multicolumn{11}{|c|}{ Model Summary ${ }^{\mathrm{b}}$} \\
\hline Model & $\mathrm{R}$ & $\begin{array}{l}\mathrm{R} \\
\text { Square }\end{array}$ & $\begin{array}{l}\text { Adjusted } \\
\text { R Square }\end{array}$ & $\begin{array}{l}\text { Std. Error } \\
\text { of the } \\
\text { Estimate }\end{array}$ & $\begin{array}{l}\text { R Square } \\
\text { Change }\end{array}$ & F Change & df1 & df 2 & $\begin{array}{c}\text { Sig. F } \\
\text { Change }\end{array}$ & $\begin{array}{l}\text { Durbin- } \\
\text { Watson }\end{array}$ \\
\hline 1 &, $343^{\mathrm{a}}$ &, 117 &, 111 & 1,05211 &, 117 & 18,932 & 66 & 854 & .000 & 1,0899 \\
\hline
\end{tabular}

NOVA ${ }^{\mathrm{a}}$

\begin{tabular}{cllrrrrr} 
Model & & \multicolumn{1}{c}{ Sum of Squares } & df & Mean Square & F & Sig. \\
\hline \multirow{2}{*}{1} & Regression & 125,736 & 6 & 20,956 & 18,932 &, $000^{\mathrm{b}}$ \\
& Residual & 945,317 & 854 & 1,107 & & \\
& Total & 1071,053 & 860 & & &
\end{tabular}

a. Dependent Variable: Learning environment management

b. Predictors: (Constant), Competence, Effectiveness Inclusive Strategies, Autonomy, Effectiveness behavior control, Relationship, Collaboration effectiveness

\begin{tabular}{|c|c|c|c|c|c|c|}
\hline \multicolumn{7}{|c|}{ Coefficients $^{\mathrm{a}}$} \\
\hline \multirow[t]{2}{*}{ Model } & & \multicolumn{2}{|c|}{$\begin{array}{c}\text { Unstandardized } \\
\text { Coefficients }\end{array}$} & $\begin{array}{l}\text { Standardized } \\
\text { Coefficients }\end{array}$ & \multirow[b]{2}{*}{$\mathrm{t}$} & \multirow[b]{2}{*}{ Sig. } \\
\hline & & $\mathrm{B}$ & $\begin{array}{l}\text { Std. } \\
\text { Error }\end{array}$ & Beta & & \\
\hline \multirow[t]{7}{*}{1} & (Constant) & 6,494 & ,332 & & 19,574 &, 000 \\
\hline & Inclusive Strategies Effectiveness &,- 306 & ,076 &,- 176 & $-4,035$ &, 000 \\
\hline & Behavior Control Effectiveness &,- 138 & ,066 &,- 088 & $-2,078$ & 038 \\
\hline & Collaborative Effectiveness &,- 076 & 069 &,- 050 & $-1,109$ & ,268 \\
\hline & Relatedness &, 060 & ,066 &, 040 & ,753901 & ,368 \\
\hline & Autonomy &,- 137 & ,039 &,- 133 & $-3,482$ &, 001 \\
\hline & Competence &,- 063 & ,083 &,- 038 &,- 743 & ,458 \\
\hline
\end{tabular}

a. Dependent Variable: Learning environment management

Linear regression analysis identified efficacy inclusive strategies $(\beta=-.176 ; \mathrm{T}=-4.035$; $\mathrm{p}=0.000)$, efficacy behavioral control $(\beta=-.088 ; \mathrm{T}=2.349 ; \mathrm{P}=0.038)$ and autonomy as significant, negative predictors of learning environment management. The remaining variables are not significant to the model. The final adjusted model is statistically significant, but weak, and explains a proportion of the observed variety in the learning environment management variable of $11.7 \%$ [F $(6,854)=18.932 ; \mathrm{p}=0.000: \mathrm{R} 2=0,117]$.

Preliminary results showed that perceived self-efficacy in inclusive strategies and comfort control, as well as autonomy, predict difficulties in controlling the environment, that is, the 


\section{6-28 February, 2021 Amsterdam, Netherlands}

higher the perceived efficacy and autonomy, the less difficulty there is in controlling the learning environment.

\section{Discussion and Conclusions}

Preliminary results showed that teaching experience negatively predicts teachers' selfefficacy in using inclusive differentiated practices, with female teachers in primary and special education considering themselves more competent in using inclusive teaching strategies. These results may be explained by the fact that at the end of their careers teachers tend to show behaviors that are the result of fatigue and career disinvestment (Gonçalves, 2009), since Hargreaves (2005) also found lower results in more experienced teachers, and Donnel and Gettiger (2015) found no relationship between experience and the implementation of differentiated strategies. However, studies by Malinen et al. (2013), identified the opposite, i.e., professional experience positively predicts levels of self-efficacy and that teacher self-efficacy is strongly correlated with the implementation of a differentiated classroom strategy (Holzberger, Philipp, \& Kunter, 2013).

Furthermore, the grade level at which teachers teach also negatively predicts not only teachers' self-efficacy in behavior control but also teachers' self-efficacy in collaboration, i.e., with primary school teachers perceiving themselves as having higher self-efficacy in behavior control and collaboration. This is in line with what Guo, Justice, and Sawyer (2011) say, since sharing knowledge of pedagogical strategies increases teachers' perceptions of efficacy.

In addition, the results showed that female teachers perceived higher needs for relationship satisfaction and competence than male teachers, and male teachers perceived themselves as having more difficulty instructing in inclusive settings. Malinen, et al. (2013), on the other hand, found that male teachers had higher levels of efficacy and felt more competent in dealing with differentiated strategies. Whereas, in Whitley et al's (2019) studies, they found that male teachers felt poorly competent to implement differentiated strategies.

Finally, the analyses showed that perceived self-efficacy in inclusive strategies and comfort control, as well as autonomy, predicted the difficulties in controlling the learning environment, i.e., the higher the perceived efficacy and autonomy, the less difficulty there was in controlling the environment. This is in line with the results of Woolfolk, Rosoff, and Hoy (1990) who found that teachers with high self-efficacy are more positive, creative, and promote more learning environments.

As a conclusion, the results show that self-efficacy and the satisfaction of basic psychological need play a key role when implementing differentiated practices. Furthermore, it was found that sociodemographic variables can interfere with and hinder the implementation of differentiated practices. Therefore, it is necessary to provide teachers with more knowledge in order to increase their self-efficacy and thus enrich their professional learning and development and apply differentiation strategies to meet the needs of all students. Despite the contributions of this study, further research should be considered, given that data collection occurred during the pandemic (some of the data collection coincided with the state of 


\section{6-28 February, 2021 Amsterdam, Netherlands}

emergency), a situation that may have influenced the data, given the excessive workload that teachers had in adapting face-to-face classes into online classes.

\section{References}

Aloe, A. M., Amo, L. C., \& Shanahan, M. E. (2014). Classroom management self-efficacy and burnout: A multivariate meta-analysis. Educational Psychology Review, 26, 101126. doi:10.1007/s10648-0139244-0

Ames, C. (1992). Classrooms: Goals, structures, and student motivation. Journal of Educational Psychology, 84(3), 261-271. doi:10.1037/0022-0663.84.3.261

Bandura, A. (1982). Self-efficacy mechanism in human agency. American Psychologist, 37(2), 122-147. doi:10.1037/0003-066X.37.2.122

Bandura, A. (1986). Social foundations of thought and action: A social cognitive theory. Englewood Cliffs, NJ: Prentice Hall.

Bandura, A. (1994). Self-efficacy. In R. J. Corsini (Ed.), Encyclopedia of psychology (2nd ed., Vol. 3, pp. 368-369). New York: Wiley.

Bandura, A. (1997). Self-efficacy: The exercise of control. New York: Freeman. 36

Bandura, A., \& Locke, E. A. (2003). Negative self-efficacy and goal effects revisited. Journal of Applied Psychology, 88(1), 87-99. doi:10.1037/0021-9010.88.1.87

Bantis, M. (2008). Using task-based instruction to provide differentiated instruction for English language learners (Unpublished master's thesis). University of South California.

Baptista, I. (2014). Carta ética: Instrumento de regulação ético-deontológica. Recuperado de http://www.spce.org.pt/PDF/CARTAETICA.pdf

Brouwers, A., \& Tomic, W. (2000). A longitudinal study of teacher burnout and perceived self-efficacy in classroom management. Teaching and Teacher Education, 16(2), 239253. doi:10.1016/S0742-051X(99)00057-8

Bzuneck, J. A. (2017). Crenças de autoeficácia de professores: um fator motivacional crítico na educação inclusiva. Revista Educação Especial, 30(59), 697-708. doi:10.5902/1984686X28427.

Cadima, A. (1997). A experiência de um círculo de estudos para uma pedagogia diferenciada. In A. Cadima, C. Gregório, T. Pires, C. Ortega, \& N. S. Horta (Eds.). Diferenciação pedagógica no ensino básico: Alguns itinerários (pp. 11-21). Lisboa: Instituto de Inovação Educacional.

Campbell, B. (2008). Handbook of differentiated instruction using the multiple intelligences lesson plans and more. Boston, Pearson Education Inc.

Caprara, G. V., Barbaranelli, C., Steca, P., \& Malone, P. S. (2006). Teachers' self-efficacy beliefs as determinants of job satisfaction and students' academic achievement: A study at the school level. Journal of School Psychology, 44(6), 473-490. doi:10.1016/j.jsp.2006.09.001

Chtena, N. (2016). Teaching tips for an UDL- Friendly classroom: Advice for implementing strategies based on universal design for learning. Retrieved from https://www.bates.edu/accessible-education/faculty/resources/

CNE (2018). Parecer: Regime jurídico da educação inclusiva no âmbito da educação préescolar e dos ensinos básico e secundário. In D. R. R. Cação, \& T. Leite (Eds.). Recuperado

de http://www.cnedu.pt/content/deliberacoes/pareceres/Parecer_Educacao_Inclusiva.pdf 


\section{6-28 February, 2021 Amsterdam, Netherlands}

Deci, E. L., \& Ryan, R. M. (1985a). Intrinsic motivation and self-determination in human behavior. New York: Plenum Press.

Deci, E. L., \& Ryan, R. M. (1985b). The general causality orientations scale: Selfdetermination in personality. Journal of Research in Personality, 19, 109-134.

Deci, E. L., \& Ryan, R. M. (1991). Intrinsic motivation and self-determination in human behavior. In R. M. Steers, \& L. W. Porter (Eds.), Motivation and work behavior (pp.458). New York: MacGraw-Hill.

Deci. E. L., \& Ryan. R. M. (2000). The what and why of goal pursuits: Human needs and the self-determination of behavior. Psychological Inquiry, 11(4), 227-268. doi:10.1207/S15327965PLI1104_01

Deci, E. L., \& Ryan, R. M. (2002). Handbook of self-determination research. Rochester, N.Y.: The University of Rochester Press.

Deci, E. L., \& Ryan, R. M. (2008). Facilitating optimal motivation and psychological wellbeing across life's domains. Canadian Psychological Association, 49(1), 14-23.

Deci, E. L., Schwartz, A. J., Sheinman, L., \& Ryan, R. M. (1981). An instrument to assess adults' orientations toward control versus autonomy with children: Reflections on intrinsic motivation and perceived competence. Journal of Educational Psychology, 73, 642-650. doi:10.1037/0022-0663.73.5.642

Deci, E. L., Spiegel, N. H., Ryan, R. M., Koestner, R., \& Kauffman, M. (1982). Effects of performance standards on teaching styles: Behavior of controlling teachers. Journal of Educational Psychology, 74, 852-859. doi:10.1037/0022-0663.74.6.852

Deci, E. L., Vallerand, R. J., Pelletier, L. G., \& Ryan, R. M. (1991). Motivation and education: The self-determination perspective. Educational Psychologist, 26, 325346. doi:10.1080/00461520.1991.9653137

Dias, P. (2017). A autoeficácia dos professores para a implementação de práticas inclusivas: contributos para uma reflexão sobre a inclusão educativa. Ensaio: Avaliação $e$ Políticas Públicas em Educação, 25(94), 7-25. doi:10.1590/s010440362017000100001

Donnell, L. A., \& Gettinger, M. (2015). Elementary school teachers' acceptability of school reform: Contribution of belief congruence, self-efficacy, and professional development. Teaching and Teacher Education, 51, 47e57. http://dx.doi.org/ 10.1016/j.tate.2015.06.003.

Eccles, J., \& Wigfield, A. (2002). Motivational beliefs, values and goals. Annual Review of Psychology, 53, 109-132. doi:10.1146/annurev.psych.53.100901.135153

Emmer, E. T., \& Hickman, J. (1991). Teacher efficacy in classroom management and discipline. Educational and Psychological Measurement, 51(3), 755-765. doi:10.1177/0013164491513027

Fernandez, A. P. O., Ramos, M. F. H., Silva, S. S. C., Nina, K. C. F., \& Pontes, F. A. R. (2016). Overview of research on teacher self-efficacy in social cognitive perspective. Anales de Psicología, 32(3), 793-802. doi:10.6018/analesps.32.3.220171

Fulmer, S. M., \& Frijters J. C. (2009). A Review of self-report and alternative approaches in the measurement of student motivation. Educational Psychology, 21, 219-246. doi:10.1007/s10648-009-9107-x

Gaitas, S., \& Martins, M. A. (2017) Teacher perceived difficulty in implementing differentiated instructional strategies in primary school. International Journal of Inclusive Education, 21(5), 544-556. doi:10.1080/13603116.2016.1223180 


\section{6-28 February, 2021 Amsterdam, Netherlands}

Gonçalves, J. A. (2009). Desenvolvimento profissional e carreira docente: Fases da carreira, currículo e supervisão. Sísifo. Revista de Ciências da Educação, 08, 23-36. Consultado em

http://centrorecursos.movimentoescolamoderna.pt/dt/3_2_formacao_professores/32_20_dese nv_profis_carreira_docente_jagoncalves.pdf

Granjo, M., \& Peixoto, F. (2012). Adaptação da escala basic need satisfaction at work para professores. In L. Mata, F. Peixoto, J. Morgado, J. C. Silva, \& V. Monteiro (Eds.), Actas do $12^{\circ}$ Colóquio Internacional de Psicologia e Educação, (pp. 381-392). Lisboa: ISPA - Instituto Universitário.

Gregory, H. G., \& Chapman, C. (2002). Differentiated instructional strategies: One size doesn't fit all. California: Corwin Press.

Guo, Y., Justice, M. \& Sawyer, B. (2011). Exploring factors related to preschool teachers' self-efficacy. Teaching and Teacher Education, 27, 961-968. doi:10.1016/j.tate.2011.03.008

Guskey, T. R., \& Passaro, P. D. (1994). Teacher efficacy: A study of construct dimensions. American Educational Research Journal, 31, 627-643. doi:10.3102/00028312031003627

Hall, T. (2002). Differentiated Instruction. Effective Classroom Practices Report. National Center on Accessing the General Curriculum. CAST, U.S. Office of Special Education Programs. Retrieved from https://eclass.upatras.gr/modules/document/file.php/PDE1342/differentiated\%20instru ction.pdf

Hargreaves, A. (2005). Educational change takes ages: Life, career and generational factors in teachers' emotional responses to educational change. Teaching and Teacher Education, 21(8), 967e983. http://dx.doi.org/10.1016/j.tate.2005.06.007.

Holzberger, D., Philipp, A., \& Kunter, M. (2013). How teachers' self-efficacy is related to instructional quality: A longitudinal analysis. Journal of Educational Psychology,

Israel, M., Ribuffo, C., \& Smith, S. (2014). Universal design for learning: Recommendations for teacher preparation and professional development (Document No. IC-7). Retrieved from http://ceedar.education.ufl.edu/wp-content/uploads/2014/08/IC7_FINAL_08-27-14.pdf

Johnson, D. (2010). Learning to teach: The influence of a university-school partnership project on pre-service elementary teachers' efficacy for literacy instruction. Reading Horizons, $\quad 50(1), \quad 23-48 . \quad$ Retrieved from https://scholarworks.wmich.edu/reading_horizons/vol50/iss1/4

Klassen, R. M., \& Chiu, M. M. (2010). Effects on teachers' self-efficacy and job satisfaction: Teacher gender, years of experience, and job stress. Journal of Educational Psychology, 102(3), 741-756. doi:10.1037/a0019237

Klassen, R., \& Tze, V. M. C. (2014). Teachers' self-efficacy, personality, and teaching effectiveness: A meta-analysis. Educational Research Review, 12, 59-76. doi:10.1016/j.edurev.2014.06.001

Kleinsasser, R. (2014). Teacher efficacy in teaching and teacher education. Teaching and Teacher Education, 44, 168-179. doi.10.1016/j.tate.2014.07.007

Malinen, O., Savolainen, H., Engelbrecht, P., Xu, J., Nel, M., Nel, N., \& Tlale, D. (2013). Exploring teacher self-efficacy for inclusive practices in three diverse countries. Teaching \& Teacher Education, 33, 34-44. https://doi.org/10.1016/j.tate.2013.02.004 


\section{6-28 February, 2021 Amsterdam, Netherlands}

Marôco, J. (2007). Análise Estatística com utilização do SPSS (3th ed). Lisboa: Edições Sílabo.

Marôco, J. (2010a). Análise Estatística com o PASW Statistics. Lisboa: Report Number.

Marôco, J. (2010b). Análise de equações estruturais: Fundamentos teóricos, software e aplicações. Lisboa: Report Number.

Marzano, R., \&. Marzano, J. S. (2003). The key to classroom management. Educational Leadership, 61, 6-13.

Masters, G. (2010). Teaching and learning: School improvement framework. Brisbane: State of Queensland (Department of Education and Training)/Australian Council for

Morgado, J. (2004). Qualidade na educação: um desafio para os professores. Lisboa: Editorial Presença.

Niemiec, C. P., \& Ryan, R. M. (2009). Autonomy, competence and relatedness in the classroom: Applying self-determination theory to educational practice. Theory and research in education, 7(2), 133-144. doi:10.1177/1477878509104318

OCDE (2012). Equity and quality in education: Supporting disadvantaged students and $\begin{array}{llll}\text { schools (Spotlight } & \text { Report). } & \text { Retrieved }\end{array}$ https://www1.oecd.org/czech/49603567.pdf

Pace, R. T., Boykins, A. D., \& Davis, S. P. (2014). A proactive classroom management model to enhance self-efficacy levels in teachers of adolescents who display disruptive behaviors. Journal of Psychosocial Nursing \& Mental Health Services, 52(2), 30-37. doi:10.3928/02793695-20130930-01

Pestana, M. H., \& Gageiro, J. N. (2008). Análise de dados para ciências sociais: A complementaridade do SPSS (5. Ed). Lisboa: Edições Sílabo, Lda.

Pentecorvo, C., Ajello, A., \& Zucchermaglio, C. (2005). Discutindo se aprende: Interação social, conhecimento e escola. Porto Alegre: Artmed.

Pereira, F., Crespo, A., Trindade, A. R., Cosme, A., Croca, F., Breia, G.,... Fernandes, R. (2018). Para uma educação inclusiva: Manual de apoio à prática. Recuperado de https://proandee.weebly.com/uploads/1/6/4/6/16461788/manual_de_apoio_a_pratica_ _1_.pdf

Reis, H., Sheldon, K., Gable, S., Roscoe, J., \& Ryan, R. (2000). Daily well-being: The role of autonomy, competence, and relatedness. Personality and Social Psychology Bulletin, 26(4), 419-435. doi.10.1177/0146167200266002

Resendes, L., \& Soares, J. (2002). Diferenciação Pedagógica. Lisboa: Universidade Aberta.

Rose, D. H., \& Gravel, J. W. (2009). Getting from here to there: UDL, global positioning systems, and lessons for improving education. In D. T. Gordon, J. W. Gravel, \& L. A Schefter (Eds.), A policy reader in universal design for learning (pp. 5-18). Cambridge, MA: Harvard Education Press.

Ryan, R. M., \& Deci, E. L. (2000a). Self-determinations theory and the facilitation of intrinsic motivation, social development, and well-being. American Psychologist, 55(1), 68-78. doi: 10.1037110003-066X.55.1.68

SPSS (2017). IBM SPSS Statistics for Windows. Armonk, NY: IBM Corp. (Version 26.0) [Computer software]. Retrieved from http://public.dhe.ibm.com/software/analytics/spss/documentation/statistics/25.0/ptBR/client/Manuals/IBM_SPSS_Statistics_Base.pdf

SPSS (2017). IBM SPSS AMOS Statistics 26. Armonk, NY: IBM Corp. (Version 26.0) [Computer software]. 


\section{6-28 February, 2021 Amsterdam, Netherlands}

Suprayogi, M. N., Valcke, M., \& Godwin, R. (2017). Teachers and their implementation of differentiated instruction in the classroom. Teaching and Teacher education, 67, 291301. doi:10.1016/j.tate.2017.06.020

Tomlinson, C. A. (2001). Differentiated instruction in the regular classroom. Understanding Our Gifted, 14(1), 3-6.

Tomlinson, C. A. (2008). Diferenciação pedagógica e diversidade: Ensino de alunos em turmas com diferentes níveis de capacidades. Porto: Porto Editora.

Tomlinson, C. A., \& Allan, S. D. (2002). Liderar projetos de diferenciação pedagógica. Porto: Edições ASA.

Tomlinson, C. A., \& Kalbfleisch, M. L. (1998). Teach me, teach my brain: A call for differentiated classrooms. Educational Leadership, 56(3), 52-55. Retrieved from https://eric.ed.gov/?id=EJ575232

Tschannen-Moran, M., \& Hoy, A. W. (2001). Teacher efficacy: capturing an elusive construct. Teaching and Teacher Education, 17, 783-805.

Tschannen-Moran, M., \& Hoy, A. W. (2007). The differential antecedents of self-efficacy beliefs of novice and experienced teachers. Teaching and Teacher Education, 23, 944-956. doi:10.1016/j.tate.2006.05.003

Tschannen-Moran, M., Hoy, A. W., \& Hoy, W. K. (1998). Teacher efficacy: Its meaning and measure. Review of Educational Research, 68(2), 202-248. doi:10.3102/00346543068002202

UNESCO (1994). Declaração de Salamanca e enquadramento da ação na área das necessidades educativas especiais. Salamanca, Espanha.

UNESCO (2015). Declaração Mundial sobre Educação para Todos. Recuperado de https://unesdoc.unesco.org/ark:/48223/pf0000086291_por

UNESCO (2017). A guide for ensuring inclusion and equity in education. Retrieved from https://unesdoc.unesco.org/ark:/48223/pf0000248254

Usher, E. L., \& Pajares, F. (2008). Self-efficacy for self-regulated learning: A validation study. Educational and Psychological Measurement, 68(3), 443-463. doi:10.1177/0013164407308475

Whitley, J., Gooderham, S., Duquette, C., Orders, S., \& J. Cousins, J. B. (2019). Implementing differentiated instruction: a mixed-methods exploration of teacher beliefs and practices, Teachers and Teaching, 25(8), 1043-1061. doi: 10.1080/13540602.2019.1699782

Wild, T. C., Enzle, M. E., Nix, G., \& Deci, E. L. (1997). Perceiving others as intrinsically or extrinsically motivated: Effects on expectancy formation and task engagement. Personality and Social Psychology Bulletin, 23, 837-848.

Woolfolk, A. E., Rosoff, B., \& Hoy, W. K. (1990). Teachers' Sense of Efficacy and Their Beliefs about Managing Students. Teaching \& Teacher Education, 6, 137-148. http://dx.doi.org/10.1016/0742-051X(90)90031-Y 